\title{
Covid-19 and Universities in Latin America
}

DOI: $10.46932 / \operatorname{sfjdv2n1-041}$

Received in: November 1st, 2020

Accepted in: December 30th, 2020

\section{Carlos Rios-Campos}

Docente universitario. Investigador RENACYT. Doctor en Gestión Universitaria. Universidad Nacional Toribio Rodríguez de Mendoza de Amazonas. Bagua, Perú.

E-mail: carlos.rios@untrm.edu.pe.

\section{Pilar Rios Campos}

Docente Principal. Maestra en Ciencias con Mención en Informática y Sistemas. Ingeniera de Sistemas. Universidad Nacional Pedro Ruiz Gallo. Lambayeque, Perú.

\section{Freddy Camacho Delgado}

Docente Principal. Doctor en Economía. Universidad Nacional Intercultural Fabiola Salazar Leguía de Bagua. Bagua Grande, Perú.

\section{Italo Maldonado Ramírez}

Decano de la Facultad de Ingeniería de Sistemas y Mecánica Eléctrica. Doctor en Administracion de la Educación. Universidad Nacional Toribio Rodríguez de Mendoza de Amazonas. Bagua, Perú.

\section{Juan Avalos Hubeck}

1Docente de Contabilidad. Maestro en Ciencias en Tributación y Asesoría Fiscal. Universidad Nacional Toribio Rodríguez de Mendoza de Amazonas. Bagua, Perú.

\section{Cristian Jurado Fernández}

Docente universitario. Doctor en Gestión Universitaria. Universidad César Vallejo. Chiclayo, Perú.

\section{Yajaira Carrasco Vega}

Docente universitaria. Maestra en Ciencias Económicas con Mención en Dirección y Organización del Talento Humano. Lic. en Administración. Universidad Nacional de Barranca. Lima, Perú.

\section{Mélida Campoverde Méndez}

Docente universitaria. Magister en Diseño Curricular. Lic. en Lengua Inglesa Especialización Lingüística y Literatura. Universidad Laica Vicente Rocafuerte de Guayaquil. Ecuador.

\begin{abstract}
It is necessary to know the state of the Universities in Latin America. The general objective was raised, to analyze the situation of Covid-19 and Universities in Latin America, considering different aspects. Methodology, the research presents a qualitative-interpretative design, documentary type, 30 documents have been selected, carried out in the period 2020 - 2021; including: scientific articles, review articles and information from websites of recognized organizations. The keywords used in the searches were: Covid19, Latin America, universities in Latin America and Covid-19 universities in Latin America. Results, COVID-19 is keeping children and adolescents around the world out of schools and universities. Conclusions, the teachers and students of Latin American universities make permanent efforts to continue their academic and research activities. COVID-19 has exposed the shortcomings in terms of infrastructure and mastery of ICTs.
\end{abstract}


Keywords: Covid-19, Latin America, universities.

\section{INTRODUCTION}

\subsection{COVID-19 AND LATIN AMERICA}

Severe acute respiratory syndrome coronavirus 2 (SARS-CoV-2) infection, which causes coronavirus disease 2019 (COVID-19), first emerged in China in December 2019 and has now spread worldwide, with a reported 351,731 confirmed cases and 15,374 deaths as of 23 March 2020 according to John Hopkins University (Hindson, 2020).

Although the focus of tackling the direct impact of COVID-19 is important, in many healthcare settings, it is important to maintain core and critical clinical service (Ting, Carin, Dzau, et al., 2020).

Severe coronavirus disease 2019 (COVID-19) is characterized by pneumonia, lymphopenia, exhausted lymphocytes and a cytokine storm. Significant antibody production is observed; however, whether this is protective or pathogenic remains to be determined (Cao, 2020).

One of the challenges in looking at the region is that every country has reacted to the pandemic in different ways, the experts agreed. Even within countries, individual towns and regions have reacted differently (Gutierrez, 2020).

The median reproductive number (Rt) for the first 10 days of the COVID-19 epidemic were 2.90 (2.67-3.14) for Spain and 2.83 (2.7-2.96) for Italy. Latin American Rt estimations were higher in Ecuador (3.95(3.7-4.21)), Panama (3.95(3.7-4.21)), and Brazil (3.95(3.7-4.21)). The smallest one was observed in Peru (2.36(2.11-2.63)). All Latin American countries had Rt greater than 2 (Caicedo-Ochoa, RebellónSánchez, Peñaloza-Rallón, Cortés-Motta \& Méndez-Fandiño, 2020).

Latin America is a region of paradoxes. It includes vast natural resources, communication and business across national borders are easy given few language and religious barriers, and there are relatively few military and religious conflicts, few cross-country rivalries relative to other parts of the world, and a steady consolidation of relatively young democracies (Aguinis, Villamor, Lazzarini, Vassolo, Amorós \& Allen, 2020).

When the COVID-19 pandemic hitLAC in late February 2020, most governments moved quickly to provide swift and decisive responses to control the outbreak and tackle its economic and social impacts (OECD, 2020).

The rapidly evolving pandemic in Brazil and other countries in Latin America begs further attention globally, given its already weak stringency for responding to the current crisis. In the spirit of our findings, we therefore recommend immediate re-evaluation of COVID-19 response in Brazil to drastically change course of action on the ground (Zhu, Raj Mishra, Han \& Santo, 2020). 
Above all, Latin American governments must act decisively to protect their populations against covid-19 while taking extreme measures to prevent an economic collapse that would exacerbate the region's pre-existing struggle against poverty and inequality (Pablos-Méndez, Vega, Aranguren, Tabish \& Raviglione, 2020).

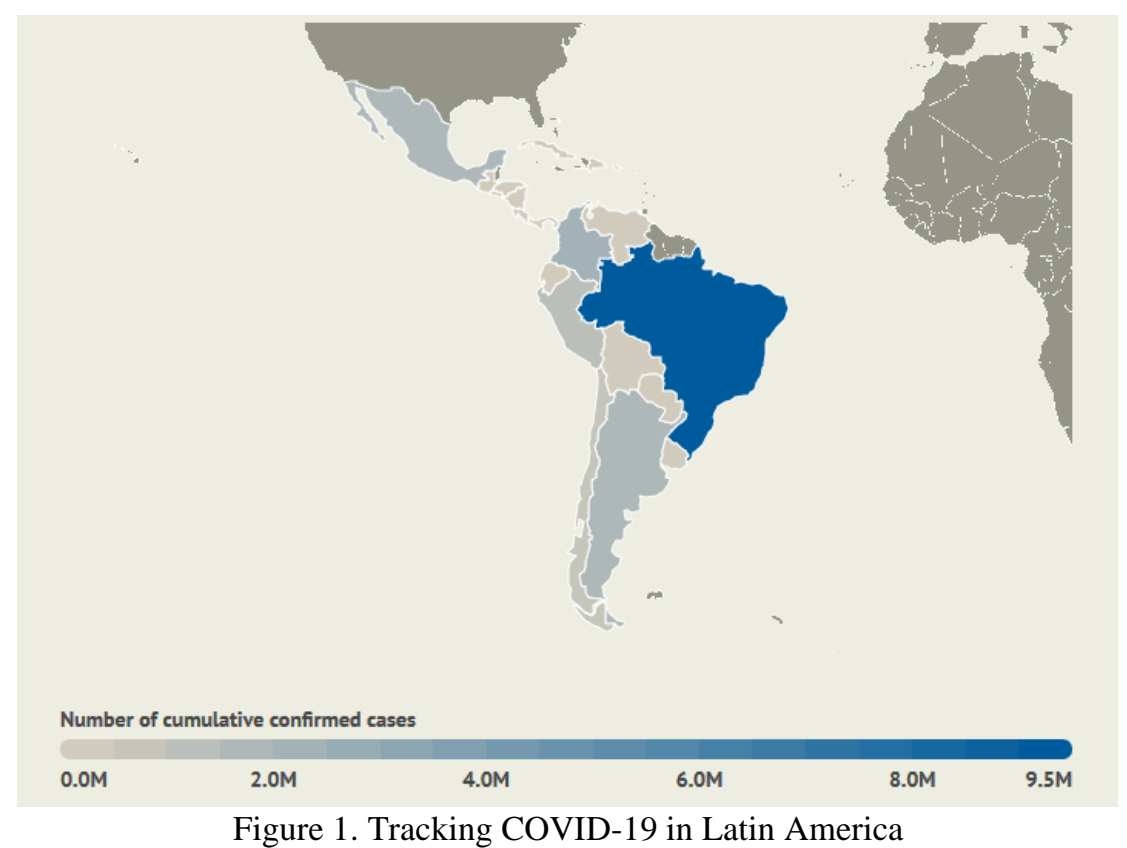

Source: Gonzalez et. al (2021)

The countries of the region show a heterogeneous evolution in the incidence of COVID-19. This heterogeneity is associated with both the public health measures adopted, as well as with the population size, poverty levels and pre-existing health systems (Acosta, 2020).

Latin America will be severely impacted by the global economic crisis that will follow the pandemic because of declines in economic activity with principal trading partners, especially China, falling commodity prices, interruption of global and regional value chains, a steep drop in the demand for tourism, and increased capital outflows from the region due to risk aversion in financial markets (Garcia, Alarcón, Bayer, Buss, Guerra, Ribeiro, Rojas, Saenz, Salgado de Snyder, Solimano, Torres, Tobar, Tuesca, Vargas, \& Atun, 2020).

At the end of February 2021, many Latin American countries are carrying out the vaccination of the population. In addition, basic economic activities are gradually being opened, in order to improve the family and national economy. 


\subsection{UNIVERSITIES IN LATIN AMERICA}

Most universities in Asia, Africa and Latin America were set up for education. Many are illequipped to perform research and lack the proper infrastructure (Onie, 2020).

Based on these developments, we explore how Latin American higher education, especially after consolidating a growing private sector, is currently moving away from the previously dominant idea of universities as institutions for educating societies' elites, an idea that is now being replaced by the increasing acknowledgment of the essential role of academic organizations in meeting demands for access to information, knowledge, job market qualifications and social mobility (Brunner \& Labraña, 2020).

By June 2019, there are ten Latin American universities positioned in the Top10 of the four Rankings, despite their differentiating characteristics and established criteria... Among the conclusions, it stands out that these universities are distinguished especially by their results in research, web presence, and web visibility showing improvements in their positioning from 2009 to 2019 (Torres-Samuel, Vásquez, Luna, Bucci, Viloria \& Vargas, 2020).

In summary, the top 10 institutions in the 2021 QS World University Rankings: Latin America are: 1. Pontificia Universidad Católica de Chile, 2. Universidade de São Paulo, 3. Tecnológico de Monterrey (ITESM), 4. Universidad de Chile, 5. Universidade Estadual de Campinas, 6. Universidad de los Andes Colombia, 7. Universidad Nacional Autónoma de México, 8. Universidad de Buenos Aires, 9. Universidade Federal do Rio de Janeiro, 10. Universidad Nacional de Colombia (QS, 2021).

The presence and better positioning in university rankings depend on institutional seniority and not on the type of ownership in Peruvian licensed universities (Dextre-Chacón, Tejedor \& RomeroRodriguez, 2020).

\section{METHODOLOGY}

The research presents a qualitative-interpretative design, of a documentary type, which specified the selection procedure and the data recording (Barrero y Rosero, 2018).

In this research, 30 documents have been selected, carried out in the period 2020 - 2021; including: scientific articles, review articles and information from websites of recognized organizations. The keywords used in the searches were: Covid-19, Latin America, universities in Latin America and Covid19 universities in Latin America. For the selection of the documents, the following criteria were used: the year of publication, belonging to the research and being a reliable source. After reading each document, the data was entered into the bibliographic matrix, which is used to catalog the documents according to categories, which are presented in Figure 1. 


\begin{tabular}{|l|l|l|l|}
\hline Name & Type & Objectives & Conclusions \\
\hline & & & \\
\hline & & & \\
\hline
\end{tabular}

Figure 1. Bibliographic matrix

Source: Adapted from Barrero y Rosero (2018).

\section{RESULTS}

It's unclear how such restrictions can persist in a region with considerable poverty and social inequality. Large numbers of Latin Americans live day-to-day on money they make from street trading and other informal work, which is now largely banned. Hunger threatens across the region (Altman \& Valarezo, 2020).

COVID-19 is keeping children and adolescents around the world out of schools and universities. In Latin America and the Caribbean, almost all countries have closed educational institutions and/or declared general quarantine to stop the spread of the pandemic (UNESCO, 2020).

Since the COVID-19 outbreak reached Latin American and Caribbean countries around three months ago, more than 28 million university students (according to UNESCO Institute for Statistics) are now learning remotely in the region. In the meantime, both universities and students are facing truly intense, unprecedented challenges in terms of technological infrastructure, financial matters and resources, among others (Suarez, 2020).

As discussed along this paper, educators are devising innovative strategies for teaching online, and getting ready for a whole new set of pandemic challenges. In this critical scenario, Design education in Latin America has a pivotal role, since it can help building back a post-pandemic society that is not just better - but far much better (Spitz, Gonzáles, Ugarte, Álvarez, Abril \& Idiáquez, 2020).

Latin American universities reacted in vastly different ways to the pandemic, either keeping their premises open and functional or closing them down and moving to e-learning (Crawford, ButlerHenderson, Rudolph, Malkawi, Glowatz, Burton, Magni \& Lam, 2020).

Campuses everywhere closed their facilities to students during the second half of March

and have yet to re-open two months later. Nearly three quarters of them transitioned to some degree of online instruction. The exceptions were all public universities, particularly in Brazil, in part for reasons noted below (Hershberg, Flinn-Palcic \& Kambhu, 2020).

In the midst of a pandemic with such a devastating and long lasting impact on social and economic rights in the Latin American region, prioritisation of innovative public policies is crucial for the future. Universities and the technology sector have taken up the challenge to confront the emergency with knowledge and ingenuity in the development of solutions (Mazzei, 2021). 
For example, organizations such as Teach for All (present in 11 countries in the region) or highquality universities can provide professionals or senior students, who are highly motivated and trained to support several of the tasks that will be required (tutoring, designing and adapting content, etc.) (Garcia, 2020).

In the case of university students in Ecuador, most of them, even in normal conditions before the pandemic, were already making great sacrifices, together with their families, to meet the economic and academic requirements needed to be admitted to, follow, and make the most of a university education (Rodríguez-Hidalgo, Pantaleón, Dios \& Falla, 2020).

This disease will negatively influence the teaching-learning process at the level of Public Higher Education in Peru. This is due to the fact that for many years it has not been invested in having a virtual campus, institutional website, digital scientific journals, minimal training of teachers and students in the management of ICTs (Ríos, 2020).

The researcher states that $45 \%$ of Brazilian universities have published articles on how to deal with COVID-19; in Colombia, 21\%; in Paraguay, 16\%; in Chile, 15\%; in Mexico, 14\%; and in Argentina, $12 \%$ of academic works have adopted the fight against the pandemic as an object of research. "The vast majority of Latin American production is generated by university researchers, but a third of the research originates from external demands. It is necessary to put an end to this divorce" (IESALC-UNESCO, 2020).

\section{CONCLUSIONS}

The teachers and students of Latin American universities make permanent efforts to continue their academic and research activities. COVID-19 has exposed the shortcomings in terms of infrastructure and mastery of ICTs. Governments must invest urgently and wisely to recover these activities. Teachers and students from low economic sectors should be provided with access to technological devices and the Internet.

Latin American universities have suffered the desertion of students and teachers. In addition, some of them have died or sick, due to COVID-19. In the case of students from private universities, due to the economic crisis they cannot cover the tuition costs. 


\section{BIBLIOGRAPHIC REFERENCES}

Acosta, L. (2020). Response capacity to the COVID-19 pandemic in Latin America and the Caribbean. Retrieved from https://www.paho.org/journal/en/articles/response-capacity-covid-19-pandemic-latinamerica-and-caribbean

Aguinis, H., Villamor, I., Lazzarini, S. G., Vassolo, R. S., Amorós, J. E., \& Allen, D. G. (2020). Conducting Management Research in Latin America: Why and What's in It for You? Journal of Management. Volume 46(5), Pages 615-636. https://doi.org/10.1177/0149206320901581

Altman, D. \& Valarezo, J. (2020). COVID-19 pandemic in Latin America. Retrieved from https://www.latrobe.edu.au/news/articles/2020/opinion/covid-19-pandemic-in-latin-america

AS/COA (2021). The Coronavirus in Latin America. Retrieved from https://www.ascoa.org/articles/coronavirus-latin-america

Barrero, A. y Rosero, A. (2018). Estado del Arte sobre Concepciones de la Diversidad en el Contexto Escolar Infantil. Revista Latinoamericana de Educación Inclusiva, 2018, 12(1), 39-55 https://doi.org/10.4067/S0718-73782018000100004

Brunner, J. \& Labraña, J. (2020). The Transformation of Higher Education in Latin America: From Elite Access to Massification and Universalisation. In: Schwartzman S. (eds) Higher Education in Latin America and the Challenges of the 21st Century. Springer, Cham. https://doi.org/10.1007/978-3-03044263-7_3

Caicedo-Ochoa, Y., Rebellón-Sánchez, D., Peñaloza-Rallón, M., Cortés-Motta, H. \& Méndez-Fandiño, Y. (2020). Effective Reproductive Number estimation for initial stage of COVID-19 pandemic in Latin American Countries. International Journal of Infectious Diseases. Volume 95, Pages 316-318. https://doi.org/10.1016/j.ijid.2020.04.069.

Cao, X. COVID-19: immunopathology and its implications for therapy. Nat Rev Immunol 20, 269-270 (2020). https://doi.org/10.1038/s41577-020-0308-3

Crawford, J., Butler-Henderson, K., Rudolph, J., Malkawi, B, Glowatz, M., Burton, R., Magni, P. \& Lam, S. (2020). COVID-19: 20 countries' higher education intra-period digital pedagogy responses. Journal of Applied Learning \& Teaching, vol. 3, no. 1, pp. 1-20 , doi: 10.37074/jalt.2020.3.1.7.

Dextre-Chacón, J.C., Tejedor, S. \& Romero-Rodriguez, L.M. (2020). Influence of institutional seniority and type of ownership on university quality rankings: correlational analysis of Peruvian universities. Journal of Applied Research in Higher Education, Vol. ahead-of-print No. ahead-of-print. https://doi.org/10.1108/JARHE-06-2020-0188

Garcia, P. J., Alarcón, A., Bayer, A., Buss, P., Guerra, G., Ribeiro, H., Rojas, K., Saenz, R., Salgado de Snyder, N., Solimano, G., Torres, R., Tobar, S., Tuesca, R., Vargas, G., \& Atun, R. (2020). COVID-19 Response in Latin America, The American Journal of Tropical Medicine and Hygiene, 103(5), 1765-1772. Retrieved Feb 26, 2021, from https://www.ajtmh.org/view/journals/tpmd/103/5/article-p1765.xml

Garcia, S. (2020). COVID-19 and primary and secondary education: the impact of the crisis and public policy implications for Latin America and the Caribbean. Retrieved from 
https://www.latinamerica.undp.org/content/rblac/en/home/library/crisis_prevention_and_recovery/covid -19-y-educacion-primaria-y-secundaria--repercusiones-de-la-.html

Gonzalez, E. et. al (2021). The Coronavirus in Latin America. Retrieved from https://www.ascoa.org/articles/coronavirus-latin-america

Gutierrez, B. (2020). COVID-19 is ravaging Latin America. Retrieved from https://news.miami.edu/stories/2020/09/covid-19-is-ravaging-latin-america.html

Hershberg, E., Flinn-Palcic, A. \& Kambhu, C. (2020). The COVID-19 Pandemic and Latin American Universities. Retrieved from https://www.american.edu/centers/latin-american-latino-studies/upload/lahigher-ed-covid-final.pdf

Hindson, J. COVID-19: faecal-oral transmission?. Nat Rev Gastroenterol Hepatol 17, 259 (2020). https://doi.org/10.1038/s41575-020-0295-7

IESALC-UNESCO (2020). The COVID-19 pandemic drives Latin American universities to research the effects of the pandemic. Retrieved from https://www.iesalc.unesco.org/en/2020/12/23/the-covid-19pandemic-drives-latin-american-universities-to-research-the-effects-of-the-pandemic/

Mazzei, H. (2021). Universities' Role in Innovation Networks to Mitigate the Effects of COVID-19: A view from Latin America. Retrieved from https://gchumanrights.org/preparedness/article-on/universitiesrole-in-innovation-networks-to-mitigate-the-effects-of-covid-19-a-view-from-latin-america.html

OECD (2020). COVID-19 in Latin America and the Caribbean: An overview of government responses to the crisis. Retrieved from https://read.oecd-ilibrary.org/view/?ref=129_129907eae84sciov\&title=COVID-19-in-Latin-Amercia-and-the-Caribbean_An-overview-of-governmentresponses-to-the-crisis

Onie, S. (2020). Redesign open science for Asia, Africa and Latin America. Nature 587, 35-37 (2020). https://doi.org/10.1038/d41586-020-03052-3

Pablos-Méndez, A., Vega, J., Aranguren, F., Tabish, H. \& Raviglione, M. (2020). Covid-19 in Latin America. BMJ 2020; 370:m2939

QS (2021). Which Institutions Topped the QS 2021 World University Rankings: Latin America?. Retrieved from https://www.qs.com/which-institutions-topped-the-qs-2021-world-university-rankingslatin-america/

Ríos, C. (2020). COVID-19 y Educación Superior Universitaria Pública del Perú. Revista Clake $\begin{array}{llllll}\text { Education. } & 1 & (2), & 1 & \text { Retrieved } & \text { from }\end{array}$ http://www.revistaclakeeducation.com/ojs/index.php/Multidisciplinaria/article/view/16/5

Rodríguez-Hidalgo, AJ., Pantaleón, Y., Dios, I. \& Falla, D. (2020). Fear of COVID-19, Stress, and Anxiety in University Undergraduate Students: A Predictive Model for Depression. Front. Psychol. 11:591797. doi: 10.3389/fpsyg.2020.591797

Spitz, R., Gonzáles, J. R., Ugarte, S., Álvarez, A., Abril, X. B. \& Idiáquez, J. M. (2020). Towards a "Better Normal": Educational Experiences in Design in Latin America During the COVID-19 Pandemic. Strategic 
Design Research Journal. Volume 13, number 03, September - December 2020. 564-576. DOI: 10.4013/sdrj.2020.133.21

Suarez, W. (2020). The stark COVID-19 challenges HE faces in Latin America. Retrieved from https://www.universityworldnews.com/post.php?story=20200619093615842

Ting, D.S.W., Carin, L., Dzau, V. et al. Digital technology and COVID-19. Nat Med 26, 459-461 (2020). https://doi.org/10.1038/s41591-020-0824-5

Torres-Samuel, M., Vásquez, C., Luna, M., Bucci, N., Viloria, A. \& Vargas, J. (2020). Characterization of Latin American Universities in the TOP10 of the Rankings. In: Vijayakumar V., Neelanarayanan V., Rao P., Light J. (eds) Proceedings of 6th International Conference on Big Data and Cloud Computing Challenges. Smart Innovation, Systems and Technologies, vol 164. Springer, Singapore. https://doi.org/10.1007/978-981-32-9889-7_9

UNESCO (2020). UNESCO update on the education sector response to COVID-19 in Latin America and the Caribbean. Retrieved from https://en.unesco.org/news/unesco-update-education-sector-responsecovid-19-latin-america-and-caribbean

Zhu, D., Raj Mishra, S., Han, X. \& Santo, K. (2020). Social distancing in Latin America during the COVID-19 pandemic: an analysis using the Stringency Index and Google Community Mobility Reports, Journal of Travel Medicine, Volume 27, Issue 8, December 2020, taaa125, https://doi.org/10.1093/jtm/taaa125 